\title{
Livelihood Security and Land Tenure Systems in Ethiopia
}

\author{
Nigatu Bekele Mengesha ${ }^{1}$ \\ School of Law, Wolaita Sodo University, Ethiopia, P.O.Box:138
}

\begin{abstract}
The article investigates the factors behind the dwindling condition of communal lands and their legal status in Ethiopia in light of the country's international and regional commitments. As the nation is comprised of an overwhelming proportion of agrarian community, who in addition to their individual farmlands for crop production, are highly dependent on communal land and resources such as timber, firewood, traditional medicine, fodder and thatching grass and places for ritual ceremonies. Currently, a nationwide, communal land on which the life of the rural mass is based on is admitted to be on the brink of literal disappearance. Even though a number of factors ranging from climate change, population growth and others may be ascribed to the dwindling of communal lands and landed resources, this study argues, through a doctrinal analysis, that the denial of legislative recognition on its part, categorically adds fuel to an unfettered extinction. Thus, the writer urges government both at federal and regional (state) level ought to accord sufficient legislative recognition of communal land tenure as well as protection of legitimate tenure rights of the rural poor which has survived for ages.
\end{abstract}

Keywords: communal land; land tenure; land rights; indigenous peoples; rural community; livelihood

DOI: $10.7176 / \mathrm{JPID} / 56-01$

Publication date: November $30^{\text {th }} 2020$

\section{I.Introduction}

Land is naturally limited resource whereas interests upon it are numerous. Individuals desire to have land for personal purposes such as building dwelling house, business premises and farming. The state on its part seeks to establish public institutions under its private domain and roads, railways, airports, recreation centers etc...falling under the public domain. Indigenous agrarian and pastoral communities also desire to make use part of the same parcel for pasture, source of water, timber, medicines, and the list goes on... Based on a number of different rationales $^{2}$, states across the world ${ }^{3}$ adopt one form of land tenure system ${ }^{4}$ or another so as to successfully respond to the differentiated interests over the land. Such land tenure systems (forms of landholding) having been manifested in governmental policies, get blessings of the lawmakers so that contrary activities will be effectively sanctioned.

Internationally, the rights of indigenous agricultural, pastoral and mixed tenure holders have got recognition in major human rights instruments. Among others, the United Nations Declaration on Rights of Indigenous People $^{5}$ (UNIDRIP) affirms that indigenous people have the right to the full enjoyment, collectively or individually, of all human rights and fundamental freedoms as recognized in the Charter of the United Nations, the Universal Declaration of Human Rights (UDHR), and International Human Rights Law.

The UNIDRIP has included the rights of the indigenous people to self-determination; freedom from discrimination; control over the development that affects them; cultural rights in economic, social, and political including education, art, and literature; recognition of their customary laws; and redress rights in the event of takings of indigenous knowledge and property. ${ }^{6}$ It confirms the right to traditional knowledge; collective rights; the right to self-determination; the right to be consulted and as a state's duty to consult; rights to lands, territories,

\footnotetext{
${ }^{1}$ Nigatu Bekele Mengesha (LL.B, LL.M) Lecturer of Law at Wolaita Sodo University, School of Law. Email: debbybekele@yahoo.com cell phone: +251913740800 . As my first journal article, in directing the how-to-write, a sheer part of the credit goes to Dr. Muradu Abdo, Associate Professor of Law, Addis Ababa University.

${ }^{2}$ Parker Shipton, Mortgaging the Ancestors: Ideologies of Attachment in Africa (Yale University Press, 2009$) 2$.

${ }^{3}$ For example Shipton claims that numerous African governments, with advice, support, and some arm twisting from outside Africa, have been gearing up at the start of the millennium to title farmland as private property in the hands of individual or group owners to make it more marketable and able to be mortgaged.

${ }^{4}$ Throughout the world, there are four very well-known land tenure systems. The first one is a private land tenure which assigns rights over land to a private party who may be an individual, a married couple, a group of people, or a corporate body such as a commercial entity or non-profit organization. The second one is communal land in which a right of commons may exist within a community where each member has a right to use independently the holdings of the community. For example, members of a community may have the right to graze cattle on a common pasture. The third one is open access land tenure system, where specific rights are not assigned to anyone and no-one can be excluded. This typically includes marine tenure where access to the high seas is generally open to anyone; it may include rangelands, forests, etc... where there may be free access to the resources for all. The last type, state land tenure, is a category in which property rights are assigned to some authority in the public sector. For example, in some countries, forest lands may fall under the mandate of the state, whether at a central or decentralized level of government.

${ }^{5}$ Resolution adopted by the General Assembly on the $107^{\text {th }}$ plenary meeting 13 September 2007 , which is not ratified by a few states, including Ethiopia.

${ }^{6}$ UNDRIP, preamble.
} 
and resources, including to strengthen and maintain their spiritual ties to the land traditionally owned, occupied, and used; and recognition of their land tenure. ${ }^{l}$ In a related manner, the International Convention on Civil and Political Rights (ICCPR), under article 1(2), prescribes that:

All peoples may, for their own ends, freely dispose of their natural wealth and resources without prejudice to any obligations arising out of international economic co-operation, based upon the principle of mutual benefit, and international law. In no case may a people be deprived of its own means of subsistence.

In response to such a strong conviction and normative global agreement, a number of high contracting parties reshuffled their national legal framework as well as institutional setup in a way that the substantive rights of a substantial segment of the people on communal land put into practice. The notable examples in this regard are the Republic of South Africa (RSA), Kenya, and most recently Liberia. While the RSA has enacted the Communal Land Rights Act, Kenya has made a profound decision to include communal land tenure in its Revised Constitution of 2010 as a third form of land tenure after the private and public land tenure system. Liberia also produced the first-ever land rights policy, in a way to protect customary ownership in which the issue of communal land tenure is a part. ${ }^{2}$

A brief historical account of the Ethiopian land tenure system depicts that the historical records are very fragmented and largely unavailable. ${ }^{3}$ It rather has been shaped by indigenous narrative sources, royal chronicles, in the first instance and, secondarily by saints' life. ${ }^{4}$ According to Daniel's findings ${ }^{5}$, there is a general tendency to divide the Ethiopian land tenure into those of the North and those of the South, because the North is the historical heartland of the empire and characterized by the communal tenure, and the South is a conquest area that has come under the domination of the North through essential private tenure system only within the last century. On the contrary, regarding the land tenure system up to the end of $19^{\text {th }}$ century, other sources indicate that communal land tenure simultaneously existed in the south. ${ }^{6}$

In contemporary Ethiopia, the issue of land tenure system hangs on the private versus state land tenure dichotomy. Scholars have fiercely argued against each other's side usually ignoring or at least not prioritizing issues of communal land tenure systems, which are practiced in over $61 \%$ of the nation's total landmass by pastoralists and other indigenous communities. Even though there is a meager provision in subordinate laws regarding communal holdings ${ }^{7}$, these laws denied a concrete and practical basis which the state and private holdings retained as such. In other words, communal land is both given by, and subject to conversion to private holding at the prerogatives of the state.

Current trends also show that the conversion is not only to private holdings, but also towards state holdings. Recently, contrary to the people's longstanding conviction, the government, having tagged vast tracts of land as 'vacant land', used to enclose it as a protected forest, park, sanctuary etc...based on the logic of 'the tragedy of the commons', or transfers to large-scale investors under the pretext of 'under-utilized' land. ${ }^{8}$ On top of that, the government overlooks arbitrary private appropriation of communal land. Be that as it may, communal land tenure system cannot be talked in the abstract; it has rather categorically become a matter of either respecting or ignoring in black and white, the rights of small-scale farming and pastoral communities, which have moved from simple positive morality to state obligations both under international law and the national laws of many countries.

As a distinct category, communal land tenure is a system which is characterized by non-exclusive use in

\footnotetext{
${ }^{1}$ Article 26 specifically provides that (1) Indigenous peoples have the right to the lands, territories and resources which they have traditionally owned, occupied or otherwise used or acquired. (2) Indigenous peoples have the right to own, use, develop and control the lands, territories and resources that they possess by reason of traditional ownership or other traditional occupation or use, as well as those which they have otherwise acquired. (3)States shall give legal recognition and protection to these lands, territories and resources. Such recognition shall be conducted with due respect to the customs, traditions and land tenure systems of the indigenous peoples concerned

${ }^{2} \mathrm{http}$ //www.land-links.org/2013/05/liberia-produces-first-ever-land-rights-policy-protects-customary-ownership accessed on 21 October 2016.

${ }^{3}$ See in general Daniel Behailu, Transfer of Land Rights in Ethiopia: Towards a Successful Policy Framework, (Eleven International Publishers, 2015).

${ }^{4}$ Id.

${ }^{5}$ Id.

${ }^{6}$ For example, in the Gofa area, from time immemorial, oral traditions indicate that men established livelihood in a freely occupied bare land and put different signs, from which afterwards, they expanded their possessions. Later on, the people, having embraced sedentary life and agriculture as a livelihood, transferred their possession to descendants as a family estate. Accordingly, the people brought about a conviction of 'mayza ma'a gadiya' to denote 'an early ancestral land'. Such a land therefore is meant to be transferrable only within the family descendants and prohibited from being sold for an outsider. Until the 'kawo's (king) emerged as the dominant traditional leader of the Gofa people, access to land was free and arbitrary. Later on, with the emergence of the kawo's however, land was granted by the bitantte (landlord) who are chosen from among the earliest settling clans of the area. There were also reported to be different kinds of lands in addition to the family holdings. Basically, land is classified as agricultural, settlement and other social services such as fields for funeral (bale), grazing, (qaa'e) wedding (yaagano) fortress (ola-mitha) and ritual ceremonies. Generally speaking, lands of special relevance such as mentioned above are under the supervision of the bitantte.

${ }^{7}$ For example, article 2(12) of proc. No. 456/2007; article 2(14) of proc. No. 110/2007(SNNPRS).

${ }^{8}$ Muradu, infra note 48,8 .
} 
which a group of people have co-equal rights. ${ }^{1}$ The resources falling in this category may include community pastures, forests, wastelands, common dumping and threshing grounds, watershed drainage, village ponds, rivers, as well as their banks and beds. ${ }^{2}$ Since access to such land is exclusive to the identified local community, management would be carried out by the community by developing certain locally crafted norms.

A number of micro-level studies in the study areas of Demba-Gofa and Zala Woredas of Gofa Zone had highlighted the significance of communal lands for the rural poor. ${ }^{3}$ The importance of communal lands lies in its potential to meet the needs of the rural masses through physical supply of substances like fodder, fuel, food, water, manure and other raw materials and also in their ability to maintain the rural agro-ecological systems. Through supply of fodder and grazing space, communal lands help individual farming households save their land for crops thereby avert the diversion of substantial proportion of crop lands from food and cash crops to fodder crops.

The writer, contends that the neglect of the concept of communal land tenure in the FDRE Constitution, the supreme law of the land and its subordinates and the subsequent enclosure of communal lands by the government itself and reluctance to deter arbitrary individual appropriation of the same in the study areas has resulted in a situation of communal land tenure insecurity, and thus total/partial loss of livelihood in the rural society of the study areas. Against this backdrop, the Article intends to examines the existing legal framework, the current livelihood security problem, experience of other countries in addressing the problem and the kind of legislative mechanism employed so as to stop the dwindling of communal lands.

This Article is organized into four sections. Accordingly, the first section is an introduction, aimed at showing the framework of the concept in general, and acting as a blueprint to navigate through. The second is a comparative experience of some countries in the form of unveiling the extent to which the concept of communal land tenure is accorded in their legal system. The third section is devoted to an investigation into the legal status of communal lands in Ethiopia, on the one hand, and the driving forces behind the dwindling pace of the same resources, on the other. Conclusions and recommendations follow.

\section{Comparative perspectives}

Although communal resources have been proposed by many scholars and international institutions like the World Bank to be either privatized or state controlled, some countries have taken careful steps for their continued independent existence. In the following paragraphs, an inquiry will be made as to how communal land and resources have been handled by some handful states. The first two of these countries are in a relatively developed economic status whereas the last two are in the least developed countries (LDC) category. These countries were purposively chosen to show that communal lands are the subject of legal discourse irrespective of economic status and also that an effort has been made to endorse the distinctiveness of communal land tenure for its own sake.

\section{- Australia}

Indigenous people of Australia comprises all persons identified as being of Aboriginal, Torres Strait Islander, or of both Aboriginal and Torres Strait Islander origin. They comprise about $2.5 \%$ of the total Australian population. A survey conducted by the Australian Bureau of Statistics (ABS) in 2012 indicates that Australia has 520,350 indigenous people comprising 90\% aboriginal only, 5\% Torres Strait Islander only and 5\% both aboriginal Torres Strait Islanders. ${ }^{4}$

Struggles over customary land rights in Australia can be traced to 1963 when seven clans of Yolgnu in the Gove Peninsular of the Northern Territory of Australia objected to the mining license which the Australian Government granted allowing bauxite to be extracted from their traditional land. ${ }^{5}$ They brought a Federal Court case, Milirrpum \& Others v. Nabalco Pty Ltd ${ }^{6}$ to establish ownership of the land in accordance with the traditional Aboriginal law. The Court ruled, in 1971, that their traditional relationship to the land could not be recognized under Australian common law. Consequently they did not hold a right to control access and could not prevent mining on their traditional land.

The government of Australia commissioned Justice Woodward to conduct an inquiry into appropriate ways to recognize Aboriginal land rights. In his findings presented in 1974, Woodward found that a land base was essential to enable Aboriginal economic development and proposed procedures for claiming, holding and dealing

\footnotetext{
${ }^{1}$ Liz Alden Wily, The Tragedy of Public Lands: The Fate of the Commons Under Global Commercial Pressure, (International Land Coalition, 2011) ILC 4., 4. 
with traditional Aboriginal land. He held that mining and other development on Aboriginal land should proceed only with the consent of the Aboriginal landowners. He argued that "...to deny Aborigines the right to prevent mining on their own land is to deny the reality of their land rights", and that the right to withhold consent should be over-ridden only if the Australian Government determined that national interest required it. ${ }^{1}$

The concept of aboriginal title was adopted by Brennan J. of the High Court of Australia in Mabo v. Queensland ${ }^{2}$ where he said that native title included the recognition of rights and interests unknown to common law: rights not necessarily analogous to common law rights "are assumed to be fully respected". Following Woodward's recommendations, the first land rights legislation in Australia, the Aboriginal Land Rights (Northern Territory) Act 1976, was passed by the Australian government. The legislation provides structures and procedures for Aboriginal people to claim, hold and manage their traditional lands. It established a procedure that returned about $40 \%$ of the northern territory to aboriginal ownership.

The Anangu Pitjantjatjara Yankunytjatjara Land Rights Act of 1981 had a similar effect in Southern Australia. In response to the Mabo decision, the Australian parliament passed the Native title Act 1993. The Act codified the doctrine and established the National native title Tribunal. In 1996, following a concern about pastoral leases, the High Court in Wik Peoples $v$ Queensland ${ }^{3}$, held that pastoral leases do not extinguish native title, and that exclusive procession was given to the lease holder. In 1996, two years after the Wik decision, parliament passed the Native Title Amendment Act 1998 which extinguished a variety of aboriginal rights over land, and provided security of tenure to non-indigenous holders of pastoral leases and other land title and gave state governments the ability to follow similar trend. ${ }^{4}$

\section{- South Africa}

South Africa is one of the African countries which obtained its independence from the colonial rule most recently i.e. in 1994. Before independence, the British colonial government ruled the country by an apartheid policy of racial segregation involving political, legal, and economic discrimination against nonwhites. The policy led to a history of conquest and disposition, forced removals, and a racially skewed distribution of land resources. It is in this context that the South African constitution promulgated in 1996 provides for land tenure security among all South Africans, irrespective of their social or economic status. ${ }^{5}$

The South African land tenure regime has for a long time been characterized by a dual tenure system with customary tenure derived from African customary law on the one hand and individualistic tenure based on the English law on the other. ${ }^{6}$ Their constitution has an elaborate bill of rights which while guaranteeing existing property rights, simultaneously requires the state to take reasonable steps to enable citizens to gain equitable access to land, promote tenure security and provide redress to those who were disposed of property as a result of past discriminatory laws and practices. ${ }^{7}$ The South African government recently enacted two national laws that have major impact on people living in communal areas, while some provinces are attempting to develop more appropriate strategies for managing land use. The laws, the Communal Land Rights Act (CLARA) and the Traditional Leaders Governance Framework Act (TLGFA), will potentially impact on how the rural poor in South Africa hold land rights and how those rights are administered. The province of KwaZulu-Natal is also developing Land Use Management. ${ }^{8}$

The CLARA was enacted to give recognition and protection of communal land rights. The objects of the Act were to transfer communal land rights to traditional communities, registration of individual land rights within communally owned areas, and use of traditional council or modified tribal authority structures to administer the land and represent the 'community' as an owner. The Act employs three broad strategies to achieve its objectives. ${ }^{9}$ The first is corporatization of land administration where communal land is transferred to and registered in the name of the resident community who must govern and administer tenure relations according to community rules. The second is individualization of communal rights in which certain old order rights are defined and registered as new order rights in the names of individuals and communities in the new order office.

\footnotetext{
${ }^{1}$ R. Palmer, Literature Review Of Governance And Secure Access To Land (Cairo: North South Consultants Exchange, 2007) in Ross Andrew Clarke, Securing Communal Land Rights To Achieve Sustainable Development In Sub-Saharan Africa: Critical Analysis And Policy Implications, (Law, Environment And Development Journal, 2009) 2/5 LEAD, 23.

${ }^{2}$ Mabo v. Queensland No. 21992 (Cth). http://foundingdocs.gov.au/item-did-33.html accessed June 14, 2013, in Friedrich Ebert Stiftung, The Legal And Policy Framework Regulating Community Land In Kenya: An A raisal (2002) 23.

${ }^{3}$ The Wik Peoples v Queensland (1996) 141 ALR 129 in Friedrich Ebert Stiftung, The Legal And Policy Framework Regulating Community Land In Kenya: An Appraisal (2002) 23.

${ }^{5}$ Leap, Perspectives on Land Tenure Security in Rural and Urban South Africa: An analysis of the tenure context and problem statement for Leap, 2005 in Friedrich Ebert Stiftung, The Legal And Policy Framework Regulating Community Land In Kenya: An Appraisal (2002) 24. ${ }^{6}$ Kameri-Mbote, and others, Ours by Right: Law, Politics and Realities of Community Property in Kenya. (Strathmore University Press, 2013) 105

${ }^{7}$ Constitution of the Republic of South Africa (No. 108 of 1996), at Article 25 (5-8)

${ }^{8}$ Id.

${ }^{9}$ E. Shlager and E. Ostrom, 'Property-Rights Regimes And Natural Resources: A Conceptual Analysis', (68/3 Land

Economics, 1992) 249.
} 
The third strategy is decentralization of public administration. Here, traditional councils, or where traditional councils do not exist, elected land administration committee administer community land rights.

Critics have however claimed that CLARA does not address some or any of the fundamental problems relating to communal land tenure in South Africa. They argue that the Act provides for a process in which "old order" or de facto rights can be identified and, confirmed, converted or transferred into "new order" rights capable of registration. What it does not provide for is either the criteria for determining what evidence counts in identifying an old order right or what processes should be followed for adjudicating multiple old order rights all competing for recognition as a new order right. ${ }^{1}$

Indeed, CLARA has been the subject of a number of court cases questioning its validity and constitutionality. In October 2008, the North Guateng High Court declared fifteen major provisions of CLARA constitutionally invalid, including the provisions for transfer and registration of communal land, determination of rights by the minister, and establishment and composition of land administration committees. ${ }^{2}$ The judgment did not find the parliamentary process to have been procedurally flawed, and did not struck down CLARA as a whole. The High Court, as it was required to do, referred the order of invalidity of CLARA to the Constitutional Court for confirmation.

In May 2010, the Constitutional Court struck out CLARA in its entirety, ${ }^{3}$ having accepted the applicants' arguments about procedural issues, and therefore, did not consider the applicants' substantive arguments or those contained in the findings of the High Court. The minister responsible for lands, having decided not to contest the judgment, chose to formulate a new legislation to govern community land. It will be interesting to see how the new law addresses the fundamental issues raised in the court cases.

\section{- Tanzania}

In Tanzania, customary land rights and practices were redefined and increasingly overridden and extinguished by the colonial and post-independence governments. During the 1970's, up to five million people were forcibly resettled into collective villages. While its theoretical benefits in terms of improved primary health, education service provision, and better communications have been slow to materialize, the "villagization" era severely disrupted customary land tenure and land management practices.

Since then, villagization was itself preceded by evictions of communities from their lands. For example, the Maasai tribes were forced to leave the Serengeti area for national park in the early 1950s, and the Barabaig forced from the Basotu plains for wheat farming in the early 1970's. These evictions have continued sporadically to the present day; for example, with the eviction of the Parakuyo Maasai from Mkomazi for a game reserve in 1988, and up to 70,000 Sukuma and other agro-pastoralists from the Ihefu swamps in 2006 ostensibly to protect a 'nationally strategic watershed' ${ }^{4}$ In the late 1970s, the few rights left in the security of customary rights derived from the country's original land legislation (the colonial Land Ordinance of 1923) had been destroyed. ${ }^{5}$

Under the Constitution of Tanzania, all land is vested in the president of the state and land rights are therefore not rights of private ownership but only of occupancy. The prospects for customary land rights in general and communal land rights in particular took a turn in the late 1990s as the country reformed its land laws. Two new land laws were passed: the Land Act of 1999 and the Village Land Act (VLA) of 1999. These were followed by the Courts (Land Disputes Settlements) Act of 2002. The Village Land Act re-established a system of village based land tenure by recognizing customary land rights and creating the means to formalize by issuing certificates of customary occupancy.

The VLA is the main legislation on community land. In its definition of what exactly constitutes "customary law", it allows for each community to freely determine their rules and practices, provided that such do not contradict the country's other laws or contravene the rights of others. ${ }^{6}$ While its primary focus is not customary land ownership, the Land Act recognizes and legalizes customary law as it applies to the assignment, transfer and definition of property rights. ${ }^{7}$ Despite the new seemingly progressive legal tenets, it has been argued in some quarters that the new land laws did not avert many of the challenges that local communities have encountered since then. These include: the continued appropriation of their land by the state and commercial

\footnotetext{
${ }^{1}$ Importantly, for the majority of sub-Saharan African communities, these de facto rights are grounded in customary norms, enforced by indigenous legal systems and may receive state recognition only to the extent customary law is recognised. Any analysis of tenure arrangements over the commons therefore requires engagement with customary, indigenous law or non-state law.

2 Tongoane and Others $v$ National Minister for Agriculture and Land Affairs and Others (11678/2006) [2009]ZAG HC127;2010(8)BCLR838(GNP)(30October2009)http://www.saflii.org/za/cases/ZAG HC/2009/127.pdf Internet accessed June 15, 2013 in Friedrich Ebert Stiftung, The Legal And Policy Framework Regulating Community Land In Kenya: An A raisal (2002) 25

${ }^{3}$ Richtersveld Community vs Alexcor, 2001 (3) SA 1293 (LCC).

${ }^{4}$ Maliasili Initiatives, Securing Community Land Rights: Local experiences and insights from working to secure hunter-gatherer and pastoralist land rights in Northern Tanzania. (Pastoral Women's Council (PWC) and Ujamaa Community Resource Team (UCRT) with Maliasili Initiatives. Tanzania: Arusha, 2012) in Friedrich Ebert Stiftung, The Legal And Policy Framework Regulating Community Land In Kenya: An Appraisal (2002) 26

${ }^{5}$ Ibid

${ }^{6}$ Village Land Act, Article 20.

${ }^{7}$ The Land Act, Preamble and Section 4(3).
} 
private sector, without proper safeguards and in ways that socio-economically disempowered them.

\section{III.The Legal Aspects of Communal Land Rights in Ethiopia}

As far as the Ethiopian jurisprudence on land tenure in general is concerned, countless critics were forwarded on matters such as the denial of the government in loosening the awkward restrictions in the transfer of land rights. This does not, however, connote that communal land rights are not affected in a decisive manner. From top to bottom, almost all legislations exhibit fundamental problems from the perspective of recognizing and protecting communal lands on which a sheer number of the rural poor depend on. Therefore, the FDRE Constitution and pertinent laws on rural land will be the subject of rigorous scrutiny in the above context.

\section{* The FDRE Constitution}

The recent Constitution, (unlike its predecessors which inculcated a tradition of a highly centralized state structure) substantially brought about decentralization of governmental power based on ethnic federalism, from which local governance over resources can be assumed. A renowned personality recited:

Since 1991, Ethiopia has embarked upon a bold experiment in the conduct of public life. The hallmark of experiment is a readiness to face the fact of ethnic diversity. New political arrangements aim to shape the Ethiopian identity around the country's constituent nations and nationalities . . . Even in this era of politics of identity, Ethiopia's resolve to extend full public recognition to her varied national communities is unique. It [the right to self determination including and up to secession] is now a constitutional entitlement. All cultural communities are entitled to fair representation in the institutions of state and federal government. Territorially based nationalities exercise wide powers of selfgovernment in political, economic, cultural and educational affairs. The result is a political order open to cultural diversity, self-expression and autonomy. ${ }^{l}$

The manner in which the principle of popular sovereignty is articulated in the Constitution influences the rights of communities as reflected in various provisions such as those related to federal structure as well as the supremacy of the Constitution. Constitutional laws normally guarantee rights and freedoms and are thus considered as 'rights documents'. In this regard, the FDRE Constitution is no exception, and almost one-third of its provisions are designated to 'Fundamental Rights and Freedoms ${ }^{e c}$. In light of the inclusion of group rights to which the Constitution anticipated the rural farming and pastoral communities as the main beneficiaries, they have the right to self-determination under the Constitution which encompasses, among other things, the right to a full measure of self-government. Such a right can be taken to mean that the Constitution is liberal as far as the exercise of communal land rights is concerned.

Nonetheless, a critical look into the Constitutional provisions display that the above assertion is not always true. In this regard, the definition of private property in the FDRE Constitution is a crystal clear example:

private property is any tangible or intangible product which has value and is produced by the labor, creativity, enterprise or capital of an individual citizen... Every Ethiopian shall have the full right to the immovable property he builds and to the permanent improvement he brings about on the land by his capital. This right shall include the right to alienate, to bequeath, and, where the right of use expires, to remove his property, transfer his title, or claim compensation for $i^{2}$

The gist of this sub-provision shows an emphasis on improvement. In other words, unless an improvement is made on land which exists naturally, it becomes hard to establish a legally enforceable right. In the words of Muradu:

The Constitution has thus adopted the concept of improvement. Under this Constitution, for any person to have a legal claim over land, they must show that they have made an improvement traceable to their labor and/or capital. One cannot claim land without establishing improvements thereon. Unimproved land in this sense belongs to the state. Those who merely extract the bare natural fruits of communal land cannot under this approach claim to have a right over those resources for they have not met the requisite condition for claiming such right. ${ }^{3}$

It is evident that one can arrive at a probability that the FDRE Constitution recognizes communal land rights by way of positive interpretation of the contents of Article 39 in a holistic approach. However, such an articulation invites a heavy debate over the issue of communal land rights. In other words, it may be argued that the collective rights mentioned under Article 39 can effectively be exercised only if the rights of NNP to own, possess and manage their communal lands using their own system are also explicitly recognized as a distinct tenure system.

Despite the fact that an abstract form of joint ownership of the people and the state over land is proclaimed in the Constitution, it was also established in black and white that the government is the only personality with the

\footnotetext{
${ }^{1}$ Andreas Eshete, Ethnic Federalism: New Frontiers in Ethiopian Politics, in proceedings of the First National Conference on Federalism, Conflict and Peace Building, Ministry of Federal Affairs of the Government of the FDRE,( Addis Ababa, 2003) p. 142 ${ }^{2}$ The 1995 FDRE Constitution, (hereafter the Constitution), Article 40 (2 \& 7).

${ }^{3}$ Muradu Abdo, State Policy and Law in Relation to Land Alienation in Ethiopia (University of Warwick, 2014$) 204$.
} 
power to administer the land. ${ }^{1}$ To put it in a nutshell, the concept of communal land tenure has no constitutional recognition in the Ethiopian legal system. Many other writers on this point stress that this kind of standing inculcates a perpetual disregard for communal land tenure:

This perpetuates the perception that community land tenure is less important and therefore, less secure form of tenure relative to private and public land tenure which are already provided for under the Land Act and Land Registration Act (of Kenya). References to community land in these laws in a sense preempts innovating landing of issues under the yet to be enacted Community Land Bill. It is therefore likely that the perception of community tenure as transient, and the parceling out of community land into individually held pieces, ostensibly as a defense against future land-grabbing, will persist. This raises the possibility that constitutional recognition of community land rights might eventually be inconsequential as the subject matter itself is fast disappearing before the necessary law can be enacted.

As will be seen immediately below in conjunction with the data obtained from the field research, the few segments of communal lands and resources for which legal scholars and other developmental partners are lobbying is on the brink of literal disappearance.

\section{* Subsidiary Legislations: The Federal Rural Land Law}

On the contrary, it has been long since a handful of African ${ }^{3}$ and other states have duly recognized the relevance of communal land tenure system into their formal legal system with the view to move in tandem with international and regional commitments pledged towards observing the rights of indigenous pastoral and smallscale agricultural as well as forest dependent communities. Concomitantly, a framework legislation on land was subsequently issued by the Ethiopian Federal Government which sets the basic tenets for the regional governments to administer the land under their respective jurisdiction.

In fact, despite the federal framework legislation governing the whole land of the nation, regional states always enact a similar legislation with an equal footing with that of the federal law. Some critics say that it is unconstitutional for regions to enact law on land, which is reserved to the federal government. The regional governments are supposed only to administer land based on the federal laws for that matter. In the next subsection, the author tries to show whether the legislation on land endorsed the concept of communal land tenure (which has long been practiced by the rural society) ${ }^{4}$.

This law is entitled as "FDRE Rural Land Administration and Land Use Proclamation." It was adopted in July, 2005 replacing its predecessor, Proclamation No. 89/1997. The scope of application of the law is throughout the country, as envisaged under Article 4 of the proclamation. Regional governments are given the power to enact rural land administration and use laws, which consists of the detailed provisions necessary to implement this proclamation. ${ }^{5}$ The proclamation states: "peasant farmers/pastoralists engaged in agriculture for a living shall be given rural land free of charge". ${ }^{6}$ Any person who is a family member of a peasant farmer, semi pastoralist or pastoralist having the right to use rural land may obtain rural land from his family by donation, inheritance or from the competent authority. ${ }^{7}$

Thus, the means of acquisition of rural land is either through family inheritance or donation, or through government provision. Since land is owned by the State and the people, peasants' title to the land is only of a usufruct in nature. The proclamation defines "communal holding" as "a rural land which is 'given by the government' to local residents for common grazing, forestry and other social services". ${ }^{8}$ It is a bare fact that human community preceded government in its modern form. It follows therefore, that such communities maintained certain identifiable plots of land for common purpose. In the ancient and medieval times, kings have accorded due regards for such communal possessions in different parts of the world. ${ }^{9}$ For example, the Kawo (king) of Gofa ethnicity in Ethiopia believed that communal land is sacred, as such. The book entitled ye gamogofa hizboch tarik has this to say:

There were also reported to be different kinds of lands in addition to the family holdings. Basically, land is classified as agricultural, grazing, settlement and other social services such as fields for funeral (bale), (qaa'e) wedding (yaagano) fortress (ola-mitha) and ritual ceremonies. Generally speaking,

\footnotetext{
${ }^{1}$ Article 40(3) of the FDRE Constitution.

${ }^{2}$ Constitution of the Republic of South Africa (No. 108 of 1996), at Article 25 (5-8)

${ }^{3}$ In this regard, the Communal Land Rights Act of the Republic of South Africa, the Community Land Bill and 2010 Constitution of Kenya are the prominent ones.

${ }^{4}$ Up to now, we have been concerned with norm changes initiated by the law to be followed by behavioral changes. But unless we define social change tautologically as identical with norm changes, which seem unjustifiable, we must accept three possible types of change- norm change followed be behavioral change, behavioral change followed by norm change or law as response to change.

${ }^{5}$ Proclamation 456/2006 Article 17(1)

${ }^{6}$ Id, Art.5(1)(a).

${ }^{7}$ Id, Art.5(2).

${ }^{8}$ Id., article 2(12)

${ }^{9}$ Ye Gamo-Gofa hizboch tarik ketint eske 1974, (Gamo-Gofa Zone Information Department, 2002), 75.
} 
lands of special relevance such as mentioned above are under the supervision of the bitantte (landlord). ${ }^{I}$

The definition of communal land in the federal rural land proclamation is an assertion that the government is the 'giver' of communal holding and thus, it is an act of putting the cart before the horse. A government which did not exist when traditional communities came into being since time immemorial can in no way claim of giving communal land. Rather, it would have better recognized that there were lands long been possessed by communities for various common purposes. The SNNPRS rural land use and administration proclamation seems a little bit aware of the age old possession of communal lands and thus followed an approach directed towards recognizing communal lands being used for long time by a given community. ${ }^{2}$

\section{* The Revised Draft Federal Rural Land Legislation}

The previous successive laws on rural land including the federal constitution, to date, experienced blatant opposition by the advocates of private ownership on accounts of lack of efficiency and refusing to release the people from indefinite, involuntary attachment to the rural land. ${ }^{3}$ Unlike the traditional expression of the law and practice, a critical look at the draft law will uncover whether the quest of communal land tenure is satisfied or not. This stems from the fact that the community is ahead of the statutory law in maintaining communal land tenure as a third distinct type. Therefore, such an incident forces one to analyze a certain empirical phenomenon in a vice-versa the practice and the law fashion. Put in a nutshell, statutory laws are in a gradual process of endorsing the behaviour of the rural community as a norm deserving sanction.

\section{* Major issues addressed}

a) Abandonment of the one-size-fits-all approach.

The absurdity of governing the whole nation by a single, uniform legislation is clearly felt by everyone. The referrals in the draft federal rural land law that majority of the details of the rules governing the land shall be decided based on laws to be enacted by regional states according to their specific circumstances may be aimed to show the departure from the one-size-fits-all approach pursued by the previous laws.

b) Dedication to observe international commitments on pastoral land rights.

The draft land law, in its preamble reiterated that due emphasis will be accorded to the customary land use and management practices of the pastoral community. The duty imposed on regional land laws to accord due recognition to customary institutions, land use, management and conflict resolution mechanisms and the attendant tasks of support and follow up ${ }^{4}$ is a good turn. This will in the future, put a tougher task on the government to follow a hands-off approach as far as respecting the integrity of communal lands on which the livelihood of the pastoralists is based.

c) Indications that land and others resources could be held communally.

Article 2(4) of the draft legislation, while defining government holding by definition through exclusion, implied that communal lands do in fact exist irrespective of governmental provision. ${ }^{5}$ This positive tendency is reinforced by a robust recognition of communal land per se in article 2(11) as a land held by local people for social, economic and other purposes. Accordingly, the phrase 'given by' is changed by the phrase 'held by'. The categories of land tenure as expressed in article 5 of the draft law are also unequivocal indication that recognition of communal land tenure is increasingly becoming an imperative.

d) Registration and certification of communal lands

The previous legislation simply provided that communal land is a land given by the government to local residents for a number of purposes. It did not provide for the registration and certification of communal lands per se. In the draft legislation, however, in addition to the recognition of communal land tenure as a distinct type of its own, registration and certification creates an opportunity through which a wholesale appropriation or gradual contraction in the size of communal lands will be abated. ${ }^{6}$ In this connection, security of communal landholdings at the time of registration is taken to be the duty of the registering organ. ${ }^{7}$

e) Conversion of communal land to private holding prohibited.

The previous legislations on land put the option of turning communal land tenure at the will and whim of the government. In other words, the mere fact that the government believes that it is feasible to do the conversion suffices to make it a reality. However, the draft law has made an unequivocal departure indicating that regional governments can dictate neither partition nor conversion of communal land to private on their own. Conversion will only be effected after having conducted sufficient research with affirmative findings and concerted

\footnotetext{
${ }^{1}$ Id.

${ }^{2}$ Proclamation no. 110/2007 Article 2(14).

${ }^{3}$ Preamble, paragraph 2, draft federal rural land proclamation of 2014

${ }^{4}$ Supra note 36 , chapter 7 , article 19.

${ }^{5}$ The draft law defines government holding as a holding which is neither private nor communal, but includes governmental holdings (which is a viscous definition resulting from poor draftsmanship), forest lands, wildlife sanctuaries and protected areas, lakes, rivers and others held in a similar nature.

${ }^{6}$ Id, Chapter 3 article 1 and 2.

${ }^{7} \mathrm{Id}$, part 4 chapter 1 , article $\left.32(3)(\mathrm{c})\right)$
} 
willingness on the part of pastoral and farming community. However, in a situation where genuine progress of rule of law is at a stake, the probability of manipulating the pure consent of the community through elite capture is feared to materialize.

\section{* Pending Issues}

a) The concern of small-scale peasants and other communal land dependent communities

The benefit that communal land yields to small-scale farmers and other poorer sections of the rural community shall not be underestimated. Even though expanding agriculture on communal lands is not as bad as such, it benefits only the farmer and his/her family blocking the fortunes of the greater multitude who lived on the resources of the communal holding. Their issue needs to be clearly and unequivocally considered in the rural land laws to be enacted in the future.

b) Rental of communal lands of pastoral and small-scale peasants

In a time when the existing communal lands are far less beyond the demands of the rural population, the possibility of renting such resources may facilitate manipulation of the interests of the mass by a few corrupt political and economic elites. ${ }^{1}$ In addition to that, the draft legislation does not clearly indicate the modality of sharing benefit gained from rental of communal lands among the inhabitants surrounding a communal land. Even though the presumption is that the local community, not the state is direct beneficiary to that end, an unequivocal indication on the issue brings about certainty at the time of enforcement.

c) Separate legislation on communal land tenure

The global, regional and local threats on communal land tenure system as exercised by indigenous peoples in sub-Saharan Africa in general and Ethiopia in particular is of such a nature that a separate legislation capable of addressing their concerns in a wholesale manner is of prime importance. Therefore, a legislation addressing solely the subject matter of communal land tenure and attendant problems need to stand on its own.

\section{IV.Conclusion and Recommendations \\ Conclusion}

The Article has investigated the legal status of communal land rights in Ethiopia from the point of view of livelihood perspective. Accordingly, the article has investigated to test the doctrinal congruency between the commitments the country has made while signing normative instruments to observe at international and regional level on the one hand and the municipal laws on the other. The bill of human rights and other soft laws of global and regional origin require that the state should not intervene in certain people's link with what they have traditionally been attached for livelihood.

After a critical look into the Ethiopian laws, unfortunately, it can be said that neither recognition nor protection is accorded to the concept of communal land rights. Even though recent legislation on rural land tends to regard communal landholding as distinct in itself, the provisions carry with themselves a number of pitfalls. Last but not least, without having the wordings for the definition of private property in the FDRE Constitution reshuffled in a way which gives full recognition to the lands to which local communities have traditional attachment, land rights as a sub-category of human rights cannot be free from obstruction.

\section{Recommendations}

Legal and policy documents revolving around land tenure in Ethiopia are based more or less, on the theory of the tragedy of the commons. Consequently, from the two alternatives offered by the proponents of this theory, i.e., privatization or state control of the commons, the latter approach (the revisionist perspective) is opted for by the Ethiopian government. Researchers such as Clarke and others have found that "theoretically sound policies in sub-Saharan Africa have either been unworkable in practice or have failed to achieve the intended objectives". In this regard, the Ethiopian legal and practical scenario is no exception. It has therefore, prompted the author to recommend the following:

First and foremost, there is a pressing need to make communal land rights equal in weight and standing to the other two forms of tenure regimes. With this conviction, the law should clearly define 'community' by making use of parameters such as: how the community is organized; the rules that hold the community together; and who holds the rights within that community. It is important note that the definition adopted for 'community' is very flexibly so as to be non-exclusionary and to allow for evolution, flexibility and adaptability over time. Definitions simply based on culture or ethnicity alone should be avoided as it can ignite inter-ethnic tensions, conflict or violence. It is also important that membership to a community should be based on use of land and not on family lineage or transfer of title. In this regard, legal proof of claims on communal land should be aligned at least, by formalizing landscape-based evidence.

Secondly, the law should clearly provide for demarcation of communal land such as maps and boundaries, in order to protect community land from encroachment. Special attention should be accorded to communal land in

\footnotetext{
${ }^{1}$ Id, chapter 7 , article 21.
} 
or around urban areas in order to ensure that they are properly vested and used. Within the communal lands, communal areas, customary rights of way and shared land use and access rights should be legally protected.

Third, the principles of protection should be clearly spelt out. These should detail among other things, how the community rights are recognized and protected; registration of rights to land; multiple land users including women and children; land use planning and sustainability issues; processes of compulsory acquisition of community land; rights of way and grazing rights; and conversion of communal land to other uses. Of particular interest is the urgent need to explicitly establish and protect women's and children's right to exercise a meaningful use right over communal land as this has traditionally been opted out in many customary practices.

Fourth, the laws should clearly state who can transact the community land on behalf of the community and the nature of permissible transactions. Here, it is important that the ultimate land rights to community land be vested in communities and not under the name of any individual members of the community to avoid cases of misappropriation of community land by group representatives as was the case in the past. The laws should also provide for and encourage the creation of community bylaws and land and natural resource management plans. Lastly, the laws should provide on how rights are to be enforced including rights and entitlements of individual members within communities. Sixth, the laws should state clearly how the community land rights are to be delivered i.e. registration of titles. As a matter of practical intervention, the author recommends the following:

In a state where transformation from agriculture towards industry in its infancy, the importance of land especially rural land is a way out to meet the needs of the ever expanding young population. Thus some portions of the CPRs may be granted for venturing into agriculture with careful scrutiny. In other words, the government shall have the duty to protect the CPRs from being grabbed by individuals who are not in a pressing need for land to meet basic items of livelihood.

To save CPRs both in size and quality, traditional institutions of CPRs administration need to come back to their revival by the assistance of the government. A strong traditional leadership in land administration with effective and conclusive decision-making power needs to be entrenched into the rural society.

The highland parts of the study area is source of many rivers such as Womba, Zenti, Maze and Lomate, which are the tributaries of the Omo River. Keeping the area as wild land (protecting from cultivation) is a best conservation scheme for ensuring sustainability of water resources especially for downstream ecosystems. So this traditional land use should be incorporated to water-shade management approach which is a key part of sustainable resource use. Being vegetation covered, the area provides some income as supplement such as for collective domestic animal rearing, and selling fodder grass. There has to be a support for efficient utilization of such small scale benefits from the CPRs.

Given the pressures of projected population growth, increased resource demand and a trend towards privatization of communal land, the commons are under increasing threat. Unclear and ineffective tenure arrangements only exacerbate the situation. Practical solutions are therefore needed now more than ever. This paper advocates for recognizing their legitimacy and empowering communities to manage the commons through secure tenure and mandating state agencies to build the effectiveness and accountability of local institutions. If the implementation issues can be overcome, increasing security of communal tenure can provide a basis for more sustainable management of the commons and offers hope that the sustainable development promised under international law can be more than rhetorical.

\section{References}

Books

Bereket, K., Land Tenure and the Common Pool in Rural Ethiopia: A Study Bases in Fifteen Sites (Blackwell Publisher, 2002).

Cousins, B. (ed), Land, Power \& Custom: Controversies Generated by South Africa's Communal Land Rights Act (UCT Press, 2008).

Daniel Behailu, Transfer of Land Rights in Ethiopia: Towards a Sustainable Policy Framework (The Hague: Eleven Publishing, 2015).

De Soto, Hernando, The Mystery of Capital: Why Capitalism Triumphs in the West and Fails Everywhere Else (New York, NY: Basic Books, 2000).

Dessalegn, R., The Peasant and the State: Studies in Agrarian Change in Ethiopia 1950-2000s (Addis Ababa University Press, 2009).

Manji, Ambreena, The Politics of Land Reform in Africa: From Communal Tenure to Free Markets (London: Zed Books, 2006)

Merera, G., Ethiopia: from Autocracy to Revolutionary Democracy, 1960s-2011 (Chamber Printing House, 2011).

Michael Quinn Patton and Michael Cochran, A Guide to Using Qualitative Research Methodology, (Medecins Sans Frontieres 2002) . 
Muradu Abdo, State Policy and Law in Relation to Land Alienation in Ethiopia (University of Warwick, 2014).

Neumann, W. L, (Social research methods - qualitative and quantitative approaches, 2000).

Ostrom, Elinor, Governing the Commons, the Evolution of Institutions for Collective Action, (Cambridge: Cambridge University Press, 1990).

Platteau, Jean Philippe, 'The Evolutionary Theory of Land Rights as Applied to Sub-Saharan Africa: A Critical Assessment, (Development and Change, 1996).

Shipton, Parker, Mortgaging the Ancestors: Ideologies of Attachment in Africa, (New Haven and London, Yale University Press, 2009).

Solomon Fikre, The Challenges of Land Law Reform, Smallholder Agricultural Productivity and Poverty in Ethiopia, PhD Thesis, (University of Warwick, School, 2015).

Ytayew A. \& Wendemagegn T, Human Rights Research: A Practical Guidebook on Methodology and Methods (Addis Ababa University Press 2013).

\section{Journal Articles and Other References}

AU, Framework and Guidelines on Land Policy in Africa, Declarations on Land issues and Challenges in Africa (Assembly/AU/Decl.1 (XIII), 2009).

Ayalew Gebre, Resource Deprivation and Changes in Pastoral Land Tenure Systems: The Case of the Karrayu in the upper Awash Valley of Ethiopia in Proceedings of the Workshop on Some Aspects of Rural Land Tenure in Ethiopia: Access, Use and Transfer, (Addis Ababa: Institute of Development Research, 2004).

Campbell, J., 'Land or Peasants? The Dilemma Confronting Ethiopian Resources Conservation' (African Affairs, 1991).

FAO, Voluntary Guidelines on the Responsible Governance of Tenure of Land, Fisheries and Forests in the Context of National Food Security (FAO, 2012).

Fassil, G.K., The Subsistence Crisis in Africa: The Case of Ethiopia (Organization for Social Science Research in Eastern Africa, Addis Ababa, 1993).

Gilbert, J., (Nomadic Territories: A Human Rights Approach to Nomadic Peoples`Land Rights, (Human Rights Law Review, 2007).

Golden, Lee and Tehan, M. (eds.), Comparative Perspectives on Communal Lands and Individual Ownership (Routledge, 2010).

Joireman, Sandra, Contracting for Land: Lessons from Litigation in a Communal Tenure Area of Ethiopia, (CJAS, 1996).

Land Policy in Africa: A Framework to Strengthen Land Rights, Enhance Productivity and Secure Livelihood (ECA Publications, 2010).

Land Tenure and Rural Development (FAO Land Tenure Studies, 2002).

Land Tenure Systems and their Impacts on Food Security and Sustainable Development in Africa (Economic Commission for Africa, 2009).

Mengistu A., Country Pasture/Forage Resource Profiles Ethiopia (FAO, 2006).

Mohammud Abdulahi, Legal Status of the Communal Land Holding System in Ethiopia: The Case of Pastoral Commnities (International Journal on Minority and Groups Rights, vol. 14, 2007).

Muradu Abdo, Rural Commons and the Ethiopian State, (Law, Social Justice and Global Development Journal, vol. 17, 2013).

Musembi, Celestine Nyamu, 'De Soto and Land Relations in Rural Africa: Breathing Life into Dead Theories about Property Rights, (Third World Quarterly, 2007).

Nettheim, G. et al., Indigenous Peoples and Governance Structures: A Comparative Analysis of Land and Resource Management Rights (Aboriginal Studies Press, 2002).

Owor, Edmond et al, Enhancing Tenure Security on Customary Land through Communal Land Associations, Paper prepared for presentation at the "2015 World Bank Conference on Land And Poverty" The World Bank - Washington DC, March, 2015),

Wickeri, E., and Kalhan, A., Land Rights Issues in International Human Rights Law (Malaysian Journal of Human Rights, 2010).

Wily, Liz Alden, Customary Land Tenure in the World: Right to Resources in Crisis: Reviewing the Fate of Customary Tenure in Africa (2012).

Wily, Liz Alden, Reconstructing the African Commons, (Africa Today, 2001).

Wily, Liz Alden, The Law Is to be Blame: The Vulnerable Status of Common Property Rights in Sub-Saharan Africa, (Development and Change, 2011) 